\title{
Decision Support System for Supplier Selection using Analytical Hierarchy Process (AHP) Method
}

\author{
Juliana $^{1}$, Jasmir ${ }^{2}$, Pareza Alam Jusia ${ }^{3}$ \\ 1,2,3 Informatics Engineering Program, STIKOM Dinamika Bangsa Jambi, Indonesia \\ Email: 1juliyana6@yahoo.co.id, ${ }^{2}$ jasmir@ stikom-db.ac.id, ${ }^{3}$ parezaalam@stikom-db.ac.id
}

\begin{abstract}
Technological growth is characterized by a variety of technological finds and computational methods used to facilitate human work in the era of globalization that is the method of Decision Support System (DSS) that helps decision makers to use data and models to solve problems that are not Structured. Toko Harapan Baru in making decisions in determining the best suppliers still use intuition, analysis, calculation and comparison of the manual in determining the supplier of goods to his shop takes a long time, the difficulty of searching data because there is no data processing cause is quite complicated without any particular method which gives inaccurate results. Then, Toko Harapan Baru requires a system that can be a solution to the problem that is being encountered. The Analytical Hierarchy Process (AHP) method is a functional hierarchy to help decision-makers better in making decisions on many objective issues.
\end{abstract}

Keywords: Decision Support Sytems, Methods Analytical Hierachy Process (AHP), Store

\section{INTRODUCTION}

In the process of management, decision-making is an important part of a company, often in the decision-making process takes a long time, manual repeated calculations, human error that may occur and difficulty in retrieval due to lack of data storage causes enough complicated without the existence of certain methods that facilitate the decision-making. Then, developed computational methods that can assist in the decision-making process, namely the computation method that developed the of decision support system (Decisions Support System) method. DSS as "Interactive Computer Based System, which helps decision makers to use data and models to solve unstructured problems" [1]. Supplier selection is an important decision-making issue in ensuring operation of a business, especially if the supplier will supply critical and long-term materials. Therefore, it is necessary to make a selection that is really able to fullfil business needs consistently and quickly with appropriate methods. Toko Harapan Baru is engaged in the business of buying and selling building materials, in decision making still using intuition, analysis, calculation and comparison manual in determining the supplier of goods to his store that can be known to require a long time and not accurate results, then it Toko Harapan Baru requires a system that can be a solution to the problems currently faced with the most appropriate decision support system method in supplier selection is the Analytical Hierarchy Process (AHP) method, delivering accurate, fast and quality results. 


\section{METHODS}

\subsection{Research Methods}

Analytical Hierarchy Process (AHP) is a functional hierarchy to help decision-makers better in making decisions on objective problems. Another goal of the AHP approach is to complement a framework and techniques of ranking viable alternatives based on the references of decision makers. This can be done because AHP is a functional hierarchy with the main input being human perception. The existence of hierarchy makes complex and unstructured problems solved into groups and arranged hierarchically [3].

Steps of AHP Method

Steps of the AHP method as follows [2]:

Define the problem and determine the desired solution.

a) In this stage we are trying to determine the problem we will solve clearly, in detail and easily understood. From the existing problem we try to find a solution that might be suitable for the problem. The solution of the problem may amount to more than one. The solution will be developed later in the next stage.

b) Create a hierarchical structure that begins with the main purpose.

After setting the main objective as the top level will be arranged hierarchy level under it that is the criteria that are suitable to consider or assess the alternatives we provide and determine the alternative. Each criterion has a different intensity. The hierarchy is followed by subcriteria (if necessary).

Table 1. Pairwise Comparison Scale [4]

\begin{tabular}{cl}
\hline $\begin{array}{c}\text { Intensity of } \\
\text { Interest }\end{array}$ & \multicolumn{1}{c}{ Information } \\
\hline 1 & Both elements are equally important \\
3 & One element is slightly more important than the other \\
5 & One element is more important than the other \\
7 & One element is clearly more absolutely essential than other elements \\
9 & One element is absolutely essential from other elements \\
$2,4,6,8$ & Values between two adjacent value judgments \\
Reverse & If for activity i get one number compared with activity $\mathrm{j}$, then $\mathrm{j}$ has the \\
& opposite value compared with i \\
\hline
\end{tabular}

c) Create a pairwise comparison matrix

The matrix used is simple, has a strong position for the consistency framework, obtains other information that may be required with all possible comparisons and is able to analyze the overall priority sensitivity for changes in consideration. The matrix approach reflects the multiple aspects of the priorities of dominating and dominating. Comparisons are based on the results of decision makers by assessing the importance of an element over other elements. To begin the pairwise comparison process we selected a 
criterion from the topmost level of the hierarchy eg $\mathrm{K}$ and then from the level below it was taken the elements to be compared eg E1, E2, E3, E4, E5.

d) Defines pairwise comparisons

Defining pairwise comparisons is made in order to derive the total number of assessments as much as

$\mathrm{n} \times[(\mathrm{n}-1) / 2]$

with $\mathrm{n}$ is the number of elements that are compared.

e) Calculate the eigenvalues of the matrix

To get the eigenvalue there are two ways that can be used namely:

1. Sums up the value of each column of the matrix, dividing each value of the column by the total of the corresponding columns to obtain the normalization of the matrix, and summing the values of each row and dividing by the number of elements to get the average [2].

2. Squares matrix of pairwise results, calculate the number of values from each row, then do the normalization matrix.

f) Repeat steps c, d and e for all levels of the hierarchy.

g) Calculates the eigenvectors of each pairwise comparison matrix. It is the weight of each element to prioritize the elements at the lowest hierarchy level to reach the goal.

h) Check the consistency of the hierarchy.

What is measured in AHP is the consistency ratio by looking at the consistency index. Consistency is expected to be near perfect to produce a decision that is close to valid. Although it is difficult to achieve perfect, the consistency ratio is expected to be less than or equal to $10 \%$. Here is how to calculate the consistency ratio.

Calculates consistency index / consistency index (CI) with the formula:

$\mathrm{CI}=((\lambda \max -\mathrm{n})) / \mathrm{n}$

$\lambda$ max is the number of times multiplying the number of columns with the main factor eigen and $\mathrm{n}$ is the number of criteria.

Calculate the consistency ratio (CR) with the formula:

$\mathrm{CR}=\mathrm{CI} / \mathrm{IR}$

With IR is the random value index corresponding to the matrix ordo.

Table 2. Index Random (RI) Value

(Kadarsyah (1998) in Ngatawi and Ira Setyaningsih's research, 2011)

\begin{tabular}{|c|c|c|c|c|c|c|c|c|c|}
\hline $\mathbf{N}$ & 1 & 2 & 3 & 4 & 5 & 6 & 7 & 8 & 9 \\
\hline RI & 0 & 0 & 0.58 & 0.9 & 1.12 & 1.24 & 1.32 & 1.41 & 1.45 \\
\hline & $\mathbf{N}$ & 10 & 11 & 12 & 13 & 14 & 15 & & \\
\hline & RI & 1.49 & 1.51 & 1.48 & 1.56 & 1.57 & 1.59 & & \\
\hline
\end{tabular}

Check the consistency of the hierarchy. If the value is more than $10 \%$, then the judgment data assessment should be improved, but if the CI /IR consistency ratio is less or equal to 0.1 then the calculation result can be stated correctly. 
The method of this study may include theories used in literature reviews obtained in the literature and must be accompanied by reference. Inform briefly about the research method used, explain how stage is.

\subsection{Similar Research Study}

In the study "Application of Analytical Hierarchy Process Method in Determining Criteria of Supplier Rating". Assessment of the supplier only focuses on current criteria and the model is not classified according to the supplier classification whereas the performance of the suppliers will affect the performance of the firm. Research to develop criteria that can be used by PT. $X$ in assessing suppliers, which can add current and future values and calculate the weight of each criterion according to the classification of the suppliers. The calculation of the criteria weights applies the Analytical Hierarchy Process method [6].

In the study "Selection Model of Dry Coconut Raw Material Supplier with AHP Method (Case Study of PT Kokonako Indonesia)." The selection of suppliers by relation-based procedures results in non-conforming dry grain raw materials and is constrained by the complexity of raw materials in terms of the large number of suppliers, the varying sizes of raw materials and the distance of different sources of raw materials. Using the Analytical Hierarchy Process (AHP) method. Research to conduct supplier selection with more comprehensive and objective considerations required. The first stage done to represent the real situation is to identify criteria, subcriteria and alternatives. The second stage, the stage of determining the method for supplier selection based on the identification of no dependence between sub criteria [7].

In the research "Selection of Supplier of Raw Material with AHP Method (Case Study of PT Nara Summit Industry, Cikarang)." PT. Nara Summit Industry, Cikarang engaged in the manufacture of automobile spare parts are distributed to spare parts manufacturers who receive many offers from suppliers. But this time, there are the same raw materials with four different suppliers that make the decision maker or Manager have to choose which suppliers are best based on the quality of the predetermined criteria of the company. Decisions can be taken based on the results of the respondents, namely the provision of questionnaires that contain the comparison between criteria and alternatives as the calculation in the selection of suppliers that will be the result of the acquisition of the questionnaire will be calculated by using a super decision tool in data processing with calculation using AHP [8].

\subsection{Research Framework}

Research framework is a relationship or link between the concept of work that one on the other work concept of the problem under study as shown in Figure 1. 


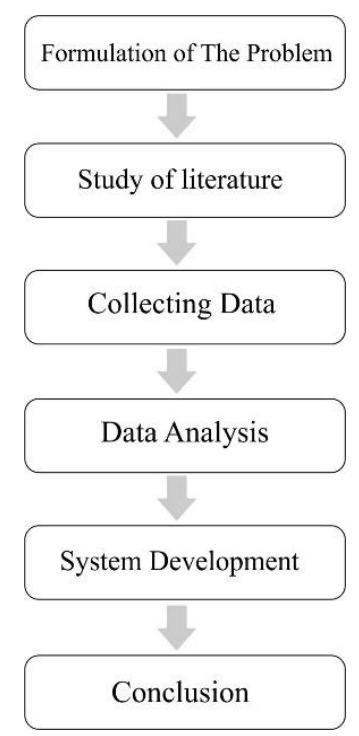

Figure 1. Research Framework

\subsection{Systems Development Method}

The method used in the development of this system is the waterfall model.

The SDLC model waterfall is often also called a sequential linnier model or classic life cycle [9]. The waterfall model shown as in Figure 2.

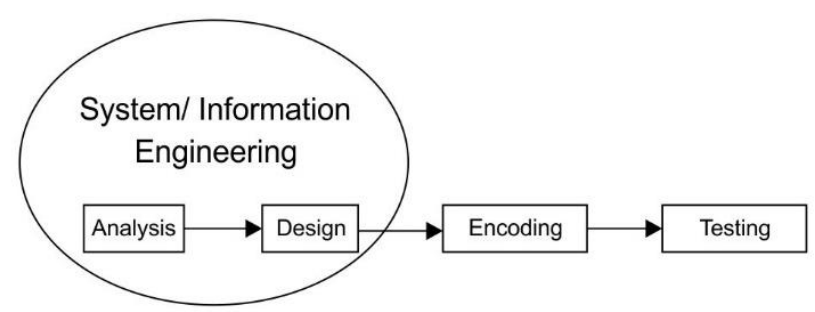

Figure 2. Waterfall Model

\section{RESULTS AND DISCUSSION}

The determination of suppliers based on initiative and self-estimate can lead to product buildup, minimize sales turnover and minimize the services provided to suppliers because incoming products can not be sold due to poor quality and quantity. The absence of a supplier selection decision system that can make reference and references that help the Toko Harapan Baru in making decisions. 
Table 3. Supplier Data Report

\begin{tabular}{clcc}
\hline Number & \multicolumn{1}{c}{ Supplier } & Address & Phone Number \\
\hline 1 & MTL (A1) & Jln Lingkar Barat & 085369145XXX \\
2 & TB Langgeng Rizki (A2) & Jln Raya & $(0741)$ 302XXX \\
& & Indrayung & \\
3 & Multi Prima Bangunan (A3) & Jln Multatuli & 085267484XXX \\
4 & TB. Tata bangunan (A4) & Jln Sumatra & $(0741)$ 687XXX \\
5 & TB. Sahabat Bangunan (A5) & Jln. Ledmund & $081279730 X X X$ \\
& & Sarniem & \\
\hline
\end{tabular}

* Phone Number $=$ Not shown in detail for keeping privacy

The criteria used are based on interviews conducted with the owner of the New Hope Store, among others, namely:

a. Cost (K1), is the cost given to the store suppliers such as sales discounts, bonuses and others

b. Payment (K2), is the time payment given suppliers to the store

c. Quality (K3), is the quality of the product offered and the selling point

d. Communication (K4), is a way of communicating suppliers to the store by providing the necessary support.

e. Service (K5), is a service supplier supplied to the store.

The steps to be taken in determining the priority criteria are as follows:

1. Create a matrix of consistency criteria as shown in Table 4.

Table 4. Matrix of Consistency Criteria

\begin{tabular}{lllllll}
\hline & K1 & K2 & K3 & K4 & K5 & PriorityVector \\
\hline K1 & 1 & 2 & 1 & 3 & 3 & 0.3098 \\
K2 & 0.5 & 1 & 1 & 2 & 2 & 0.2015 \\
K3 & 1 & 1 & 1 & 5 & 3 & 0.3031 \\
K4 & 0.3333 & 0.5 & 0.2 & 1 & 1 & 0.089 \\
K5 & 0.3333 & 0.5 & 0.3333 & 1 & 1 & 0.0966 \\
Number & 3.1666 & 5 & 3.5333 & 12 & 10 & 1 \\
\hline
\end{tabular}

$\mathrm{CR}$ value with the provision must be smaller than 0.1 as a condition if accepted consistency criteria, and the following is the calculation:

Principle Eigen Value $\lambda \max =3.1666 * 0.3098+5 * 0.2015+3.5333 * 0.3031+12$

$* 0.089+10 * 0.0966=5.0934$

Consistency Index CI $(($ sigma max-n $) /(n-1))=(5.0934-5) /(5-1)=0.0233$

Consistency Ratio CR $(\mathrm{CI} / \mathrm{IR})=0.0233 / 1.12=0.02$

The Criteria Consistency Matrix of Cost, Payment, Qualtiy, Communication, and Service as shown in Table $5-9$. 
Table 5. Criteria Consistency Matrix of Cost

\begin{tabular}{cllllll}
\hline Cost & \multicolumn{1}{c}{ A1 } & \multicolumn{1}{c}{ A2 } & \multicolumn{1}{c}{ A3 } & A4 & $\begin{array}{c}\text { A5 } \\
\text { Priority } \\
\text { Vector }\end{array}$ \\
\hline A1 & 1 & 3 & 0.5 & 5 & 4 & 0.2875 \\
A2 & 0.3333 & 1 & 0.33 & 5 & 3 & 0.1689 \\
A3 & 2 & 3.0303 & 1 & 7 & 5 & 0.422 \\
A4 & 0.2 & 0.2 & 0.1429 & 1 & 0.5 & 0.0464 \\
A5 & 0.25 & 0.3333 & 0.2 & 2 & 1 & 0.0753 \\
Amount & 3.7833 & 7.5636 & 2.1729 & 20 & 13. & 1.0001 \\
& & & & & 5 & \\
\hline
\end{tabular}

After getting the priority vector then we look for CR with the provision should be smaller than 0.1 as a condition if accepted consistency criteria, and the following is the calculation:

a. Principle Eigen Value $\lambda \max =3.7833 * 0.2875+7.5636 * 0.1689+2.1729 *$ $0.422+20 * 0.0464+13.5 * 0.0753=5.2268$

b. Consistency Index CI $(($ sigma max-n $) /(n-1))=(5.2268-5) /(5-1)=0.0567$

c. Consistency Ratio CR $(\mathrm{CI} / \mathrm{IR})=0.0567 / 1.12=0.05063$

Table 6. Criteria Consistency Matrix of Payment

\begin{tabular}{clllllll}
\hline Payment & \multicolumn{1}{r}{$\mathbf{A 1}$} & \multicolumn{1}{c}{$\mathbf{A 2}$} & \multicolumn{1}{c}{$\mathbf{A 3}$} & $\mathbf{A 4}$ & $\mathbf{A 5}$ & $\begin{array}{c}\text { Priority } \\
\text { Vector }\end{array}$ \\
\hline A1 & 1 & 3 & 3 & 5 & 3 & 0.4271 \\
A2 & 0.3333 & 1 & 0.33 & 3 & 0.33 & 0.1128 \\
A3 & 0.3333 & 3.0303 & 1 & 3 & 1 & 0.1992 \\
A4 & 0.2 & 0.3333 & 0.3333 & 1 & 0.33 & 0.0613 \\
A5 & 0.3333 & 3.0303 & 1 & 3.0303 & 1 & 0.1996 \\
Amount & 2.1999 & 10.393 & 5.6633 & 15.0303 & 5.66 & 1 \\
\hline
\end{tabular}

Table 7. Criteria Consistency Matrix of Quality

\begin{tabular}{ccccccc}
\hline Quality & A1 & A2 & A3 & A4 & A5 & $\begin{array}{c}\text { Priority } \\
\text { Vector }\end{array}$ \\
\hline A1 & 1 & 1 & 1 & 1 & 1 & 0.2 \\
A2 & 1 & 1 & 1 & 1 & 1 & 0.2 \\
A3 & 1 & 1 & 1 & 1 & 1 & 0.2 \\
A4 & 1 & 1 & 1 & 1 & 1 & 0.2 \\
A5 & 1 & 1 & 1 & 1 & 1 & 0.2 \\
Amount & 5 & 5 & 5 & 5 & 5 & 1 \\
\hline
\end{tabular}

Table 8. Criteria Consistency Matrix of Communication

\begin{tabular}{ccccccc}
\hline Communcication & $\mathbf{A 1}$ & $\mathbf{A 2}$ & $\mathbf{A 3}$ & $\mathbf{A 4}$ & $\mathbf{A 5}$ & $\begin{array}{c}\text { Priority } \\
\text { Vector }\end{array}$ \\
\hline A1 & 1 & 3 & 5 & 7 & 5 & 0.5132 \\
A2 & 0.3333 & 1 & 3 & 2 & 3 & 0.2171 \\
A3 & 0.2 & 0.3333 & 1 & 2 & 1 & 0.1009 \\
A4 & 0.1429 & 0.5 & 0.5 & 1 & 0.5 & 0.0679 \\
A5 & 0.2 & 0.3333 & 1 & 2 & 1 & 0.1009 \\
Amount & 1.8762 & 5.1666 & 10.5 & 14 & 10.5 & 1 \\
\hline
\end{tabular}


Tabel 9. Criteria Consistency Matrix of Service

\begin{tabular}{clllllll}
\hline Service & A1 & A2 & A3 & A4 & A5 & $\begin{array}{c}\text { Priority } \\
\text { Vector }\end{array}$ \\
& & & & & & & 0.3231 \\
A1 & 1 & 2 & 2 & 3 & 2 & 0.3172 \\
A2 & 0.5 & 1 & 3 & 5 & 3 & 0.3177 \\
A3 & 0.5 & 0.3333 & 1 & 3 & 1 & 0.147 \\
A4 & 0.3333 & 0.2 & 0.3333 & 1 & 0.33 & 0.0653 \\
A5 & 0.5 & 0.3333 & 1 & 3.0303 & 1 & 0.1474 \\
Amount & 2.8333 & 3.8666 & 7.3333 & 15.030 & 7.33 & 1 \\
& & & & 3 & & \\
\hline
\end{tabular}

2. Determining Results

The priority of the calculations in steps 1 and 2 is then poured into the matrix. The result matrix as shown in Table 10.

Table 10. Result Matrix

\begin{tabular}{cccccccc}
\hline Numb. & Criteria & Weight & A1 & A2 & A3 & A4 & A5 \\
\hline 1 & Cost & 0.3098 & 0.2875 & 0.1689 & 0.422 & 0.0464 & 0.0753 \\
2 & Payment & 0.2015 & 0.4271 & 0.1128 & 0.1992 & 0.0613 & 0.1996 \\
3 & Quality & 0.3031 & 0.2 & 0.2 & 0.2 & 0.2 & 0.2 \\
4 & Communication & 0.089 & 0.5132 & 0.2171 & 0.1009 & 0.0679 & 0.1009 \\
5 & Service & 0.0966 & 0.3231 & 0.3172 & 0.147 & 0.0653 & 0.1474 \\
Composite Weight & & 0.3126 & 0.1856 & 0.2547 & 0.0997 & 0.1474 \\
\hline
\end{tabular}

After obtaining the result matrix, the decision support system will provide a sequence of results for suppliers from best to worst. The final result assessment as shown in Table 11.

Table 11. Final Results Assessment

\begin{tabular}{clc}
\hline Numb. & \multicolumn{1}{c}{ Supplier } & Total Score \\
\hline 1 & MTL & 0.3126 \\
2 & Multi Prima Bangunan & 0.2547 \\
3 & TB Langgeng Rizki & 0.1856 \\
4 & TB. Sahabat Bangunan & 0.1474 \\
5 & TB. Tata Bangunan & 0.0997 \\
\hline
\end{tabular}

3. Modeling the sytem

Use case describes an interaction between one or more actors with the information system to be created. Roughly speaking, use cases are used to find out what functions exist within an information system and who is entitled to use those functions. The use case diagram is shown in Figure 3. 


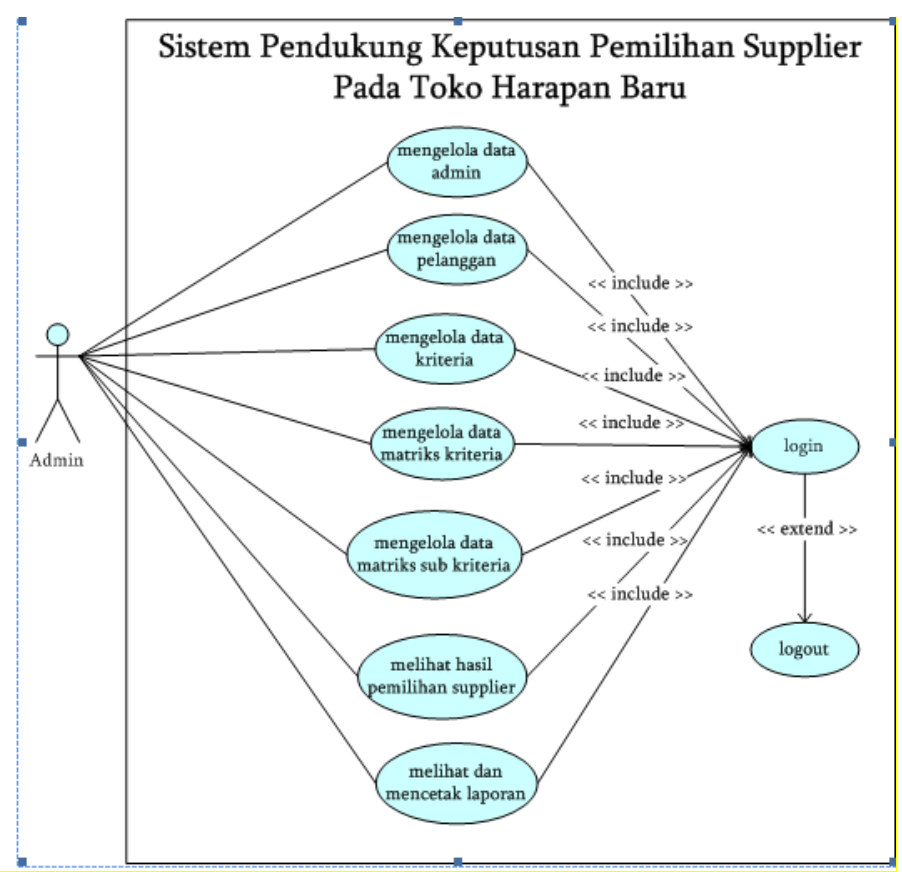

Figure 3. Use Case Diagram

Class diagrams or class diagrams describe the structure of the system in terms of defining classes that will be created to build the system. The interface of Supplier Selection Result is shown in Figure 4. 


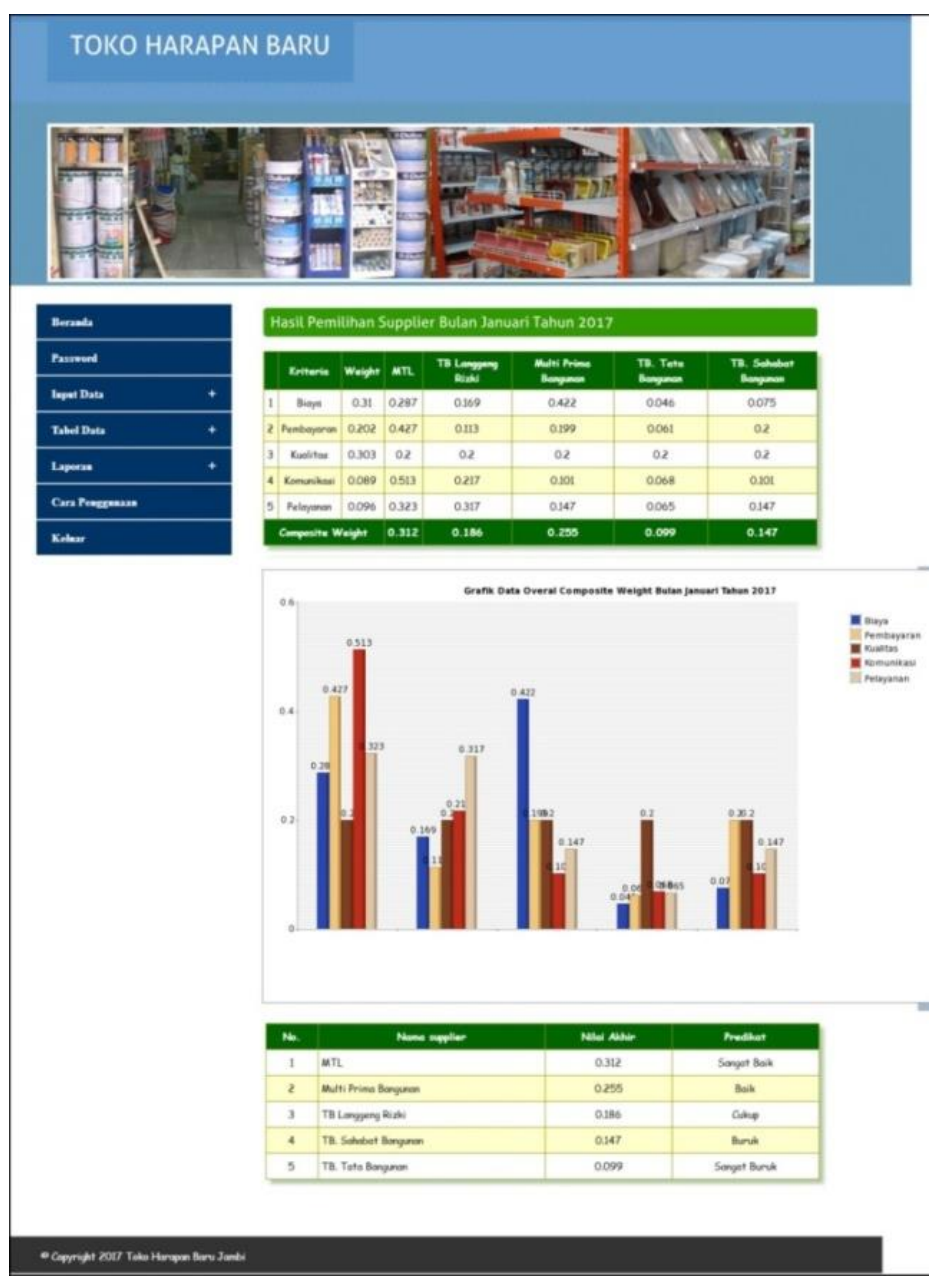

Figure 4. Supplier Selection Result

\section{CONCLUSION}

The result of decision support system using Analytical Hierarchy Process (AHP) method at Toko Harapan Baru stated that MTL as the best supplier with the highest score or excellent predicate is 0.312 than Multi Prima Bangunan of 0.255 , TB Langgeng Rizki is 0.186, TB Sahabat Bangunan is 0.147 and the smallest score of 0.099 for TB Tata Bangunan. With the system can compare the criteria, namely Cost, Payment, Quality, Communication and Services and Supplier is the TB. Tata Bangunan, MTL, Multi Prima Bangunan, TB Langgeng Rizki and TB Sahabat Bangunan. For the New Hope Shop, the system gives approximately 120 seconds faster in the selection of suppliers with computerized data. Thus, the results are more accurate, faster and easier in the search data back and prevent the occurrence of human error. 


\section{REFERENCES}

[1] Sarwindah, S., 2013. Kajian Pemilihan Software Desain Grafis untuk Pembelajaran dengan Metode AHP Studi Kasus SMK Muhammadiyah 9. Semnasteknomedia Online, 1(1), pp.09-39.

[2] Astradanta, M., Wirawan, I.M.A., and Arthana, I.K.R., 2016. Pengembangan Sistem Pendukung Keputusan Pemilihan Tempat Kuliner dengan Metode AHP dan SAW (Studi Kasus: Kecamatan Buleleng). KARMAPATI (Kumpulan Artikel Mahasiswa Pendidikan Teknik Informatika) ISSN: 2252-9063, 5(2).

[3] Viarani, S.O. and Zadry, H.R., 2016. Analisis Pemilihan Pemasok dengan Metode Analitycal Hierarchy Process di Proyek Indarung VI PT Semen Padang. Jurnal Optimasi Sistem Industri, 14(1), pp.55-70.

[4] Ngatawi dan Ira Setyaningsih. 2011. Analisis Pemilihan Supplier Menggunakan Metode Analytic Hierarchy Process (AHP). Jurnal Ilmiah Teknik Industri. Yogyakarta : Universitas Islam Negeri Sunan Kalijaga.

[5] Wirdianto, E. and Unbersa, E., 2008. Aplikasi Metode Analytical Hierarchy Process dalam Menentukan Kriteria Penilaian Supplier. Jurnal Teknik Industri, 2(29).

[6] Wardah, S. and Surya, R.Z., 2014. Model Pemilihan Pemasok Bahan Baku Kelapa Parut Kering Dengan Metode AHP (Studi Kasus PT. Kokonako Indonesia). MIEJ, 3(1).

[7] Astuti, P., 2016. Pemilihan Supplier Bahan Baku dengan Metode AHP STUDY KASUS PT. NARA SUMMIT INDUSTRY, CIKARANG. Jurnal Teknologi Informasi dan Komunikasi, 7(1), pp.39-48.

[8] Rosa, A.S. and Shalahuddin, M., 2013. Rekayasa Perangkat Lunak Terstruktur dan Berorientasi Objek. Bandung: Informatika. 